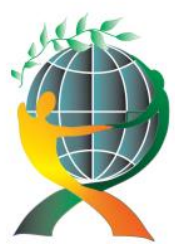

\author{
(online) $=$ ISSN $2285-3642$ \\ ISSN-L = $2285-3642$ \\ Journal of Economic Development, Environment and People \\ Volume 10, Issue 3, 2021 \\ URL: http://jedep.spiruharet.ro \\ e-mail: office jedep@spiruharet.ro
}

\title{
Evaluation of The Active Labor Market Policies in The Republic of Srpska
}

\author{
Velinka Tomić \\ Faculty of Production and Management Trebinje, University of East Sarajevo \\ The Republic of Srpska, Bosnia and Herzegovina
}

\begin{abstract}
This paper discusses the methods of evaluating active labor market policy. In addition, an important aspect of the analysis, conducted in this paper, concerns the assessment of the relative success of these measures in the case of the Republic of Srpska. The statistical analysis evaluated the success of three chosen projects implemented in the Republic of Srpska. A major problem in evaluating the effectiveness of individual measures is inadequate IT support. The unemployed persons are not monitored for all the characteristics that play a significant role in determining the target groups for particular measures. The measures are primarily intended for young people and categories related to the recent war conflicts in the former Yugoslavia. The relative assessment of the success of individual measures has confirmed that these measures are not greatly influenced by raising general employment, but these programs, at least to some extent, alleviate the problem of unemployment and improve the position of the hard-to-employ categories of the unemployed persons.
\end{abstract}

Keywords: Active labor market policies, unemployment, employment, evaluation, vulnerable categories of the unemployed, The Republic of Srpska

JEL Codes: J08, J48

How to cite: Tomić, V. (2021). EVALUATION OF THE ACTIVE LABOR MARKET POLICIES IN THE REPUBLIC OF SRPSKA. Journal of Economic Development, Environment and People, 10(3), 86-98. doi:

http://dx.doi.org/10.26458/jedep.v10i3.703

\section{Introduction}

Labor market policies target the unemployed and others who have particular difficulties entering or returning to the labor market. All labor market interventions, according to the methodology used by Eurostat, can be classified into the following three groups: services, active labor market policies (ALMP) and passive labor market policies (Eichhorst, Werner \& Konle-Seidl, Regina 2016) [6].

ALMP in the Republic of Srpska are aimed at increasing the quality and quantity of jobs, promoting social inclusion and gender equality. Two-thirds of all programs in the previous decade were intended to improve the employability of vulnerable groups in the labor market: young people without work experience, women, returnees and Roma.

With the increase of the funds for ALMP in the Republic of Srpska, the question of the expediency of the funds spending was arisen. Although it can be heard that ALMP is largely a waste of public funds, they are more advocates of active measures as an instrument to combat unemployment and exclusion from the labor market. Since the funds for ALMP measures are mainly collected from the employed workers, it is necessary 


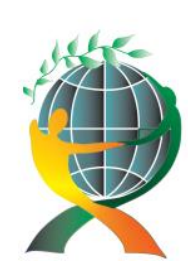

\author{
(online) $=$ ISSN $2285-3642$ \\ ISSN-L = $2285-3642$ \\ Journal of Economic Development, Environment and People \\ Volume 10, Issue 3, 2021 \\ URL: http://jedep.spiruharet.ro \\ e-mail: office jedep@spiruharet.ro
}

to qualitatively assess the impact of the measures and make the necessary adjustments in accordance with their cost-effectiveness.

\title{
2. Evalution Methods
}

The research evaluation methods of ALMP have evolved with development of the information technology. The first few papers on development of the methodology of evaluations written in the USA, a considerable number of papers have been published on the topic of evaluation in Western Europe. In the last decade, more papers have been written in the former transition countries of Central and Eastern Europe. A survey conducted by Lehman \& Klueveu in 2010 found that ALMP have an effect on both increasing the employability of individuals' unemployment and increasing employment, especially in developed countries (Lehmann, H. \& Kluve, J. 2010) [10].

Evaluation can be micro and macro evaluation: assessing the impact of the program or measure on an individual is micro evaluation, but macro evaluation is examining whether there has been a change in terms of net social gain (Hujer et al. 2002) [9]. The evaluation of the ALMP can be carried out as:

- Performance measurement, i.e. monitoring of program functioning and number of participants, salary levels, costs, etc.

- Impact evaluation, which answers whether the program has achieved its desired goals and what the impact of the measures was

- Cost-benefit analysis, which addresses the opportunity cost of the program

- Process evaluation, which monitors the processes in the implementation of measures and identifies shortcomings that occur during implementation of the measure (Harrell et al. 1996) [8].

The methods for evaluating the impact of labor market programs can be scientific and unscientific. The second methods are also called non-experimental and rely entirely on statistics. Their use is limited, as they do not allow assessment in terms of measure as a cause of change in the labor market status. Further, scientific evaluations can be experimental and nonexperimental i.e. quasi-experimental. The basic difference between them is in the way the units are allocated to the sample, whether the selection of units in the target and control group was made by the random sample method, or the control group was formed subsequently ignoring the rule of random arrangement of units in the sample (Dar, A. \& Tzannatos, Z. 1999) [4].

There are different divisions in the literature, based on a similar methodological approach. Martin J.P. (2000) divides evaluations into two main groups: the first group measures the impact on employment and the earnings of individuals after leaving the program, and the second group measures the net effect of the program on aggregate employment and unemployment. De Koning J, Peers Y. (2007) evaluate the net effect using experimental and non-experimental models. Non-experimental methods include the pairing and econometric methods. Lehmann \& Kluve (2010) for the evaluations use both: macroeconomic and microeconomic methods, depending on the data used. Administrative data are the basis for macroeconomic access, as well as the data from the unemployment register and the Labor Force Survey for microeconomic access. 


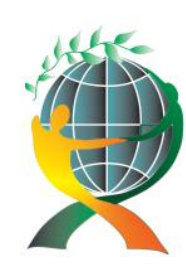

\author{
(online) $=$ ISSN $2285-3642$ \\ ISSN-L = $2285-3642$ \\ Journal of Economic Development, Environment and People \\ Volume 10, Issue 3, 2021 \\ URL: http://jedep.spiruharet.ro \\ e-mail: office jedep@spiruharet.ro
}

In addition, there is a Meta approach in evaluating ALMP, which summarizes the results of a number of studies previously conducted and identifies measures that have been the most successful, less successful and unsuccessful. First Meta-analysis by Dar, A. \& Tzannatos, Z. (1999) summarized the results of about 100 studies, mainly for OECD countries. The meta-analysis conducted by Card, D., Weber, A. \& Kluve, J. (2010) also summarizes the results of 97 studies conducted on the effects of ALMP.

The largest number of ALMP evaluations in the past three decades has consisted of evaluations in North America and Western Europe (OECD (1993), Martin (2000), Daguerre, Etherington (2009) and others.). The first papers on the methodology of evaluation were written in the United States of America, but in the last two decades the number of papers in this field has increased among researchers in transition countries of Central and Eastern Europe.

\title{
2.2. Experimental Method
}

The experimental method of the evaluation is characterized by the fact that persons were selected in the observed sample at random, before the intervention itself, before exposure to measures. By influencing on the independent variables (participating in the measure), it is possible to measure what changes have occurred in the results. These changes can be attributed to the participation in the ALMP in such conditions, since the participants are chosen completely randomly. The assumption is that the participants in the control and treated group are not significantly different. Moreover, the results obtained are not only applicable to the individuals involved in the experiment, but to the entire target audience. Therefore, the experimental method is considered as the "gold standard" of the impact evaluation (Harrell et al. 1996) [8].

The selection of participants in the experiment is carried out in two steps. In the first step, a sample is randomly selected from the group intended for conducting the experiment. In the second step, the sample is divided into two groups: the experimental group, which will participate in the experiment, and the control group, which will not be subjected to the measure. Both groups have been monitored for a sufficiently long period to assess the impact of the measure on employment of participants in relation to employment of nonparticipants. (de Koning, J., Peers, Y. 2007 [5].

Proponents of the experimental method point out that random selection of participants in a measure ensures the absence of bias in the choice among participants, as well as the impact on the behavior of participants in the measure. However, contrary claims can be found in the literature that the bias caused by random selection of participants in the sample can be quite strong. Individuals who plan to participate in a program or measure may have completely different behavior than if they were randomly selected to a group, called the "Hawthorne effect" (Dar, A. \& Tzannatos, Z. 1999) [4].

When selecting participants in these groups by surveying, some participants are not willing to participate in the measures, but they can also be selected in the experimental group. The studies list a number of factors that influence experiments in terms of bias results. The instruments that would be used to correct the effect of preference in experimental methods are, in fact, already developed instruments for non-experimental methods. The measure implementation procedure itself during the experiment most frequently differs from the implementation procure without conducting the experiment.

In addition to the random selection of participants, the experimental method can also be characterized by a random selection of the period when the measure will be implemented. As a special variant of the experimental method, Harrell state a prolonged onset, when one group of participants, randomly selected, is included in the measure, and the other group of participants after a certain time. The main disadvantage 


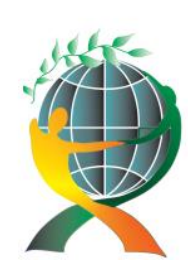

\author{
(online) $=$ ISSN $2285-3642$ \\ ISSN-L = $2285-3642$ \\ Journal of Economic Development, Environment and People \\ Volume 10, Issue 3, 2021 \\ URL: http://jedep.spiruharet.ro \\ e-mail: office jedep@spiruharet.ro
}

of this variant is the short period for evaluating the results between the completion of the program of the first group and the beginning of the program for the second group of participants.

Although the experimental method is preferred for assessing the impact of a measure on a scientific basis, the random distribution of participants in the sample is not always the best choice for assessing the effectiveness of measures (having in mind the factors and conditions of real life). Some measures will not have an effect on the participants, nor can their effectiveness be assessed by applying the experimental method and random distribution to the observed and control group. As an example, the literature cites measures intended for children, some ethnic groups and especially vulnerable persons (Harrell et al. 1996) [8].

Experimental methods are very expensive, because a large sample is needed to implement them. Disadvantages of experimental methods include problems with the selection of a random sample and changes in the behavior of participants after learning about participation in the measure. The ethical side of the experimental method is mentioned as a special shortcoming, because only certain groups of participants are allowed to participate in the measure, and other groups and persons are prevented from participating. Another reason may be of a legal nature, as legislation in some countries prohibits this type of exclusion.

Some researchers dispute this shortcoming by asking whether it is considered unethical to implement a measure, among a large number of the unemployed, not knowing whether the measure has beneficial effects on participants or even side effects? If the experiment is expected to have a favorable net effect of measures, with reasonable certainty, then this is a valid reason to temporarily exclude some groups of the unemployed from a certain measure (De Koning, J. Peers, Y. 2007) [5].

\title{
2.3. Nonexperimental method
}

Non-experimental (quasi-experimental) methods are generally applied after the implementation of an employment policy program, based on the data collected by the researcher himself, or from official administrative sources, or in both ways. The first step in conducting an evaluation of a measure with this type of evaluation method is to form an observed group of participants in that measure. The selection of participants in the control group will depend on the characteristics selected in this group. There are several ways to form a control group. These can be individuals who have given up the program, individuals who could have participated in the measures according to their characteristics, but did not participate, or e.g. individuals from another geographical unit with the required key features, if the measure is geographically situated in a particular local area.

The comparison does not have to be only between such selected groups, the observed and control ones. There are studies that confirm that the observed group can be compared with the outcomes of another group with different characteristics in terms of age or gender, with the outcomes of some other programs and measures, and even with the outcomes of groups in some other countries. Even more recent studies are sometimes referred to as "weakly experimental evaluations" (Pierre, G. 1999) [11].

Evaluation generally takes the form of statistical analysis, but it can also contain simple comparisons of outcomes. Statistical analysis implies that outcomes are variables that need to be interpreted through the interpretation of a series of variables that affect them. For example, if the outcome is employability after completion of the program or implementation of a measure, then the set of variables to be considered when assessing the outcome consists of external factors that may affect, such as geographical region, industry, etc., individual characteristics (age, education, work experience, etc.) and variables that indicate whether an individual has participated in a given program or not. By measuring the influence of the last group of 


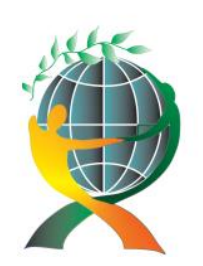

\author{
(online) $=$ ISSN $2285-3642$ \\ ISSN-L = 2285 - 3642 \\ Journal of Economic Development, Environment and People \\ Volume 10, Issue 3, 2021 \\ URL: http://jedep.spiruharet.ro \\ e-mail: office jedep@spiruharet.ro
}

variables, in fact, the main effect of participation in the measure on the outcome is determined, i.e. employability.

Related to this, there is the division of non-experimental methods into the following:

- Regression analysis with monitoring of unobserved variables

- Regression analysis of observed and unobserved variables

- Pairing method.

By measuring the impact of variables by gender, age, the level of education, work experience, etc., which differ in the target and control group, it is possible to assess the impact of the measure on the variable, i.e. on employability. By taking into analysis the unnoticed, immeasurable factors such as innate abilities or behavioral changes with participation in the program, it is possible to more accurately assess the effect of participation in a measure on the final outcome. The pairing method leads to an even safer comparison result through the formation of a sub-group within the control group with the connection of the members of the observed group with the control group members who have the appropriate "paired factors".

The issue of proper selection of the control group is very important in non-experimental methods, because better outcomes of the observed group compared to the control group may be the result of the characteristics of individuals in the group, rather than participation in a program or measure ALMPs. Motivation of individuals (involved in the program) to achieve better results can affect the outcome and lead to overestimation of results when evaluating an ALMP measure.

Therefore, in the evaluation of effects with this method, econometric techniques are used to correct the inequality of the two groups, the observed and control ones. The advantage of evaluation applying the nonexperimental method is primarily in the cost of implementation, but also in the fact that the evaluation process and the implementation of active measures are completely independent.

In addition to the described methods and evaluations, evaluations aimed at assessing the net effect or contribution of the program to aggregate employment and unemployment are important, along with evaluating the effects of externalities, such as "deadweight", substitution effect and substitution effect. Due to the existence of these effects, the social benefit of the program is lower than the one obtained through the evaluation of impacts through these methods. Such impact evaluations are suitable for programs such as subsidies for self-employment, employment, public works and the similar (Dar, A. \& Tzannatos, Z. 1999) [4].

It can be said that the common shortcoming of both groups of methods, experimental and nonexperimental ones, is precisely in the insensitivity to the mentioned effects. The methods cannot reveal how many participants replaced the already employed workers, i.e. whether it is a matter of actually matching labor supply and demand, or whether the unemployed participant and the employed worker have just swapped positions in the labor market. Another form of the substitution effect occurs when the employer hires a worker because of subsidies, instead of a worker who is not entitled to a subsidy, i.e. is not included in the ALMP measure, and is even more favorable choice for a given job.

The "dead burden" assessment provides an answer to the question of the number of individuals who would be employed and not be involved in some measure, i.e. "dead weight" occurs when the result of a program is not different from what would have been achieved without that program. The substitution effect appears with an increase in the volume of production of enterprises, which employed workers through subsidies, while at the same time the production is decreased in enterprises that did not do that (Calmfors $\mathrm{L}$. 


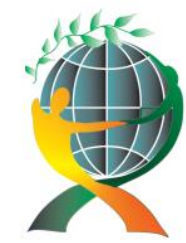

\author{
(online) $=$ ISSN $2285-3642$ \\ ISSN-L = $2285-3642$ \\ Journal of Economic Development, Environment and People \\ Volume 10, Issue 3, 2021 \\ URL: http://jedep.spiruharet.ro \\ e-mail: office jedep@spiruharet.ro
}

1994) [2]. The gross effect of a program is measured by the number of new employees or the number of new jobs. The net effect of the ALMP measure is obtained through the following form:

Net effect of the measure = Gross effect - "dead weight" - substitution effect - substitution effect

In addition, some researchers use non-experimental impact assessment methods to examine changes in the level of risk or outcome among the program or group participants, without forming control groups of other participants or groups that are not exposed to the measure. The four basic types of non-experimental methods defined in this way are:

- Comparison of participants before and after participation in the program or measure

- Time series based on measuring results, before and after the implementation of the program

- Panel analysis based on repeating the measurement of outcomes of the same group of participants

- Comparison of groups of participants after participating in the measure.

These simply designed models are based on the analysis of aggregate data, are easy to perform and practically free of charge (Harrell et al. 1996) [8]. Although at the individual level the impact of the program can be positive, the effect at the community or country level can be significantly different, being the reason to be necessary to combine these methods and analyzes, and thus evaluate the effectiveness of implemented ALMP (Fay, R. G. 1996) [7].

\title{
3. Active Employment Policy Measures in The Republic of Srpska
}

ALMP in the Republic of Srpska can be said to be aimed at increasing the quality and quantity of jobs and to promote social inclusion and gender equality, as two thirds of all programs are aimed at improving the employability of vulnerable groups in the labor market: young people without work experience, women, returnees and Roma. The Public institution, the Employment Office of the Republic of Srpska (EORS) is responsible for implementation of the employment policies in the Republic of Srpska. In 2018, these programs covered 4,866 people, for which over 15 million BAM were spent (Employment Office of the Republic of Srpska 2018) [12]. The following table shows an overview of the most important ALMP programs in 2019 in the Republic of Srpska:

Table 1. ALMP programs in 2019 in the Republic of Srpska

\begin{tabular}{|l|l|c|}
\hline \multicolumn{1}{|c|}{ Program } & Target Group & $\begin{array}{c}\text { Amount } \\
\text { (BAM) }\end{array}$ \\
\hline $\begin{array}{l}\text { Program to encourage the } \\
\text { development of } \\
\text { entrepreneurship among } \\
\text { young startups Srpska }\end{array}$ & Young people up to 35 years of age - recorded by the EORS & 3.600 .000 \\
\hline $\begin{array}{l}\text { Employment support } \\
\text { program for young people } \\
\text { with a university degree in }\end{array}$ & - 100 children of killed soldiers with a university degree & \\
\hline
\end{tabular}




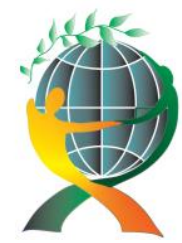

\author{
(online) $=$ ISSN $2285-3642$ \\ ISSN-L = $2285-3642$ \\ Journal of Economic Development, Environment and People \\ Volume 10, Issue 3, 2021
}

URL: http://jedep.spiruharet.ro

e-mail: office jedep@spiruharet.ro

\begin{tabular}{|c|c|c|}
\hline $\begin{array}{l}\text { the status of trainees in } \\
2019 \text { (total } 200 \text { people) }\end{array}$ & $\begin{array}{l}\text { - } 100 \text { young people with a university degree without work } \\
\text { experience }\end{array}$ & 1.495 .522 \\
\hline $\begin{array}{l}\text { Employment support } \\
\text { program in the economy } \\
\text { through the payment of } \\
\text { incentives in the amount of } \\
\text { paid taxes and } \\
\text { contributions in } 2019\end{array}$ & $\begin{array}{l}\text { - Long-term unemployed } \\
\text { - Persons with low qualifications (persons with the secondary } \\
\text { school completed and lower qualifications) registered for at } \\
\text { least six months } \\
\text { - Women registered for at least six months } \\
\text { - Persons aged } 40 \text { and over registered for at least six months } \\
\text { - Hard-to-employ persons, namely: persons with disabilities, } \\
\text { former residents of Homes for abandonded children, victims } \\
\text { of violence, single parents and parents of seriously ill } \\
\text { children, regardless of the period of being recorded. }\end{array}$ & 4.125 .000 \\
\hline $\begin{array}{l}\text { Training, additional training } \\
\text { and retraining program in } \\
2019\end{array}$ & $\begin{array}{l}\text { Unemployed persons ending with IV degree qualifications, } \\
\text { who are actively seeking employment and are registered as } \\
\text { unemployed. }\end{array}$ & 300.000 \\
\hline $\begin{array}{l}\text { The Employment support } \\
\text { Program for Roma in the } \\
\text { Republic of Srpska in } 2019\end{array}$ & Roma & 203.710 \\
\hline $\begin{array}{l}\text { Employment and self- } \\
\text { employment financing } \\
\text { program in } 2019 \text { "Together } \\
\text { to the job" } \\
\text { (total } 195 \text { people) }\end{array}$ & $\begin{array}{l}\text { - Demobilized soldiers } \\
\text { - War invalids and children of killed soldiers }\end{array}$ & 1.000 .000 \\
\hline $\begin{array}{l}\text { Employment and self- } \\
\text { employment program of } \\
\text { target categories in the } \\
\text { economy in } 2019 \\
\text { (total 1,225 persons) }\end{array}$ & $\begin{array}{l}\text { - Persons older than } 40 \text { years, } \\
\text { - Women victims of domestic violence and war torture in } \\
\text { rural areas } \\
\text { - Residents of Homes for abandoned children who have } \\
\text { completed their education } \\
\text { - Persons who have been recorded for more than six } \\
\text { months }\end{array}$ & 5.002 .478 \\
\hline
\end{tabular}

Source: EORS http://www.zzzrs.net/index.php/projekti/vlastiti/Accessed on 10.10.2020.

In the Republic of Srpska, the employment programs in 2017 included primarily young people without work experience and the long-term unemployed. In 2018, the project was implemented to subsidize employers who submit applications for hiring new workers and the project to finance the education programs aimed at raising the competitiveness of workers. These two public calls included the employment of 1,336 people from the unemployment register.

The characteristics of implementation of the measures is the uncertainty of the inflow of funds for implementation of the program, and thus the difficulties in planning all the necessary activities. Considering the results, measured by labor market indicators, it can be said that ALMP programs are monotonous and insufficiently creative, and that they do not include people who are at the most disadvantaged. Therefore, it 


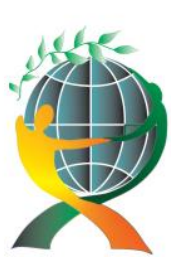

\author{
(online) $=$ ISSN $2285-3642$ \\ ISSN-L = $2285-3642$ \\ Journal of Economic Development, Environment and People \\ Volume 10, Issue 3, 2021 \\ URL: http://jedep.spiruharet.ro \\ e-mail: office jedep@spiruharet.ro
}

is necessary to assess the effectiveness of each program, in order to achieve a better connection between the unemployed and jobs, i.e. to raise the program efficiency.

\title{
3.1. Evaluation of the success of selected ALMP measures in the Republic of Srpska
}

Papers and studies related to the success of the implemented ALMP measures in $\mathrm{BiH}$ are not present, which leads to the conclusion that the success of the implemented measures in BiH has not been evaluated so far. Data from the database of the National Employment Office were used to analyze the success of individual ALMP measures. Although this analysis is limited for several reasons, among which are certainly the difficulties in classifying participants into groups (because they can be in several target groups at the same time), it is possible to make a statistical analysis that can give a rough assessment of the success of the respective ALMP measures in the labor market of Republic of Srpska.

The analysis of the success of the measures was realized as follows:

Step 1. Target groups of those excluded from the labor market were identified, which participated to some extent;

Step 2. The number of employees from the records of the employment office for the observed target group was determined;

Step 3. The participation of employees was determined by applying the ALMP measure in the total number of employees in the observed group;

Step 4. The "dead burden" of application of the measure was assessed, i.e. the number of persons who would have been employed and had not participated in the project was determined and

Step 5. The efficiency of each observed measure based on the performed budget in the previous steps was assessed (Babic, 2003) [1].

In the Republic of Srpska, the Employment Office divides measures in the field of employment cofinancing into the following groups:

A1- SSNESP Project - (unemployed persons in a state of social need, family members of killed, arrested and missing soldiers, war invalids and civilian victims of war);

A2- Project "Together to the job" - (demobilized soldiers, war invalids and children of killed soldiers);

A3- Project for trainees "With Knowledge to the job" - (young people up to 35 years of age, who have no work experience in the profession).

The effectiveness of individual measures cannot be assessed for all categories of unemployed persons for whom a particular measure is intended, due to the lack of such registration of the unemployed with the Employment Office. It is also not possible to determine the level of successfulness of any vulnerable group, because belonging to such a category is proven only when applying for participation. Namely, if the measure is intended for different categories such as, e.g. measure A2, then the total number of persons who can be beneficiaries of the measure according to the given characteristics, i.e. who can apply to participate in the measure.

Only certain categories of the unemployed, such as the disabled or young people up to the age of 35, are monitored in total. At the same time, it is not identified how many young people have a characteristic such as "children of killed soldiers". Therefore, the analysis of the effectiveness of individual measures for the RS was done only for certain vulnerable groups that could participate in the measure. However, given 


\author{
(online) $=$ ISSN $2285-3642$ \\ ISSN-L = $2285-3642$ \\ Journal of Economic Development, Environment and People \\ Volume 10, Issue 3, 2021 \\ URL: http://jedep.spiruharet.ro \\ e-mail: office jedep@spiruharet.ro
}

that these are the measures that directly lead to employment of the participants, it is not possible to highlight the success of this projects. Only after checking the status of these persons and receiving feedback on the status after a certain period of time, it is possible to say that the goal, i.e. employment of hard-to-employ groups like war invalids, was achieved. The following Table 2 shows the calculation of the success of individual measures for individual groups of unemployed that the Employment Office implemented in 2012. This year was chosen as the base year, due to the many positive characteristics that determine it in relation to the years that preceded it and those that followed:

Table 2. Relative evaluation of the successfulness of ALMP measures in RS

\begin{tabular}{|c|c|c|c|c|}
\hline & Target group of unemployed persons & $\begin{array}{l}\text { Unemployed age } \\
\text { over } 40 \text { years }\end{array}$ & $\begin{array}{l}\text { War } \\
\text { invalids }\end{array}$ & $\begin{array}{l}\text { Young up } \\
\text { to } 35 \text { years }\end{array}$ \\
\hline 1. & $\begin{array}{l}\text { Unemployed } \\
\text { at the beginning of the year }\end{array}$ & 68.739 & 2.466 & 39.368 \\
\hline 2. & Total employees during the year & 7.803 & 332 & 7.568 \\
\hline 3. & Number of requests received & 3.988 & 157 & 2.336 \\
\hline 4. & Number of employees through the measure & 805 & 89 & 1.435 \\
\hline 5. & Employed persons without measures & 6.998 & 243 & 6.133 \\
\hline 6. & Planned volume of employment & 4.000 & 300 & 1.500 \\
\hline 7. & $\begin{array}{l}\text { Share of employees with measures in total } \\
\text { employment }\end{array}$ & $10,32 \%$ & $26,81 \%$ & $18,96 \%$ \\
\hline 8. & $\begin{array}{l}\text { Share of employment of the target group with } \\
\text { measures }\end{array}$ & $1,17 \%$ & $3,61 \%$ & $3,65 \%$ \\
\hline 9. & $\begin{array}{l}\text { Share of employment of the target group } \\
\text { without measure }\end{array}$ & $10,18 \%$ & $9,85 \%$ & $15,58 \%$ \\
\hline 10. & $\begin{array}{l}\text { "Dead burden", } \\
\text { expressed by the number of employees }\end{array}$ & 82 & 9 & 224 \\
\hline 12. & Net contribution to target group employment & $9,27 \%$ & $24,17 \%$ & $16,01 \%$ \\
\hline
\end{tabular}

Source: Author's calculation, based on internal data of the Employment Office 


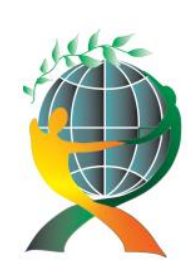

\author{
(online) $=$ ISSN $2285-3642$ \\ ISSN-L = $2285-3642$ \\ Journal of Economic Development, Environment and People \\ Volume 10, Issue 3, 2021 \\ URL: http://jedep.spiruharet.ro \\ e-mail: office jedep@spiruharet.ro
}

3,988 persons applied for participation in the Project of Support to Social Protection Networks and Employment, out of which 805 persons or $20 \%$ of unemployed persons in 2012 got a job through the project. The project offers support through self-employment, employment with employers, training programs, retraining and additional training, improving labor mobility and public works.

For the category of unemployed over the age of 40 who were subjected to some measure from the project, the planned volume of employment was 4,000 persons. Only one-fifth of the planned volume of employment was achieved in 2012. The causes have not been fully determined, but it can be concluded that this is a project that includes measures that immediately achieve employment, but also measures that should increase the employability of certain categories of the unemployed, such as training, retraining or additional training.

The employment rate for the observed group of the unemployed over 40 years of age through the project is significantly below the employment rate of this category without participation in the project, i.e. $1.17 \%$ and $10.18 \%$, respectively. However, the net contribution to employment of the target group of the unemployed of $9.27 \%$ tells us that the applied measures contribute to employment, but also that it is possible to achieve better results, primarily through better linking of measures and categories of the unemployed for whom they are intended, and by redefining the measures themselves.

The project "Together to the job" is intended for unemployed demobilized soldiers, war invalids (WI), but also for the children of killed soldiers of the RS Army. The project covers the employment of a total of 425 persons of the above categories of unemployed from the records for a period of at least 12 months, who are actively seeking a job and are registered with the Employment Office, through co-financing of selfemployment and employment with employers.

The success of this project can be analyzed only for the WI category, because in the records of the RS Employment Office, the unemployed with the characteristics of children of killed soldiers and demobilized soldiers are not registered, but the given characteristic is proven when applying for participation in the project. A total of 300 WIs could apply for employment and self-employment measures. At the beginning of 2018, there were 2,466 war invalids on the records of the Employment Office.

The employment rate of WIs that were involved in the measure was $3.61 \%$, and for WIs that did not participate in the project, it was $9.85 \%$. For this vulnerable category of unemployed, the net contribution of measures to total employment is significant, even $24.17 \%$. The reasons why all persons who applied for the project were not allowed to participate in the measures should be sought primarily in the non-fulfillment of conditions for participation, so that only $50 \%$ of applicants received funds for self-employment or are employed by the employer.

In base year young people up to the age of 35 were able to participate in the project "With Knowledge to the job". The employment rate of participants in the project in base year is $3.65 \%$. The employment rate of young people who did not participate in the project is significantly higher, even $15.58 \%$. The net contribution of this measure to the youth employment in base year is $16.01 \%$. Table 3 shows how much interest was shown for each measure and the ratio of the planned and realized employment based on the implementation of the measure.

As presented in the table, the number of received requests is much higher than the realized employment. Only $20 \%$ of the unemployed, over the age of 40 were included in the measure, about $57 \%$ of war invalids and about $61 \%$ of young people. According to the criterion of the planned/realized employment, the most successful employment measure is intended for young people with a ratio of $95.67 \%$. This indicator 


\author{
(online) $=$ ISSN $2285-3642$ \\ ISSN-L = $2285-3642$ \\ Journal of Economic Development, Environment and People \\ Volume 10, Issue 3, 2021 \\ URL: http://jedep.spiruharet.ro \\ e-mail: office jedep@spiruharet.ro
}

for the measure Together to the job, (intended for War invalids) is about a third of the planned employment, and for the first measure only one fifth of the planned or $20 \%$.

Table 3. Planned and realized employment in \%

MEASURE

\begin{tabular}{|c|c|c|c|}
\hline & $\begin{array}{c}\text { Social Welfare and } \\
\text { Employment Networks } \\
\text { Support Project }\end{array}$ & $\begin{array}{c}\text { Project: } \\
\text { "Together to the } \\
\text { job" }\end{array}$ & $\begin{array}{c}\text { Project for trainees: } \\
\text { "With Knowledge to the } \\
\text { job" }\end{array}$ \\
\hline $\begin{array}{c}\text { Target group of unemployed } \\
\text { persons }\end{array}$ & $\begin{array}{c}\text { Unemployed over } 40 \\
\text { years }\end{array}$ & War invalids & $\begin{array}{c}\text { Young people up to } 35 \\
\text { years }\end{array}$ \\
\hline $\begin{array}{l}\text { Number of employees } \\
\text { through the } \\
\text { measure/number of } \\
\text { requests received }\end{array}$ & 20,19 & 56,69 & 61,43 \\
\hline $\begin{array}{l}\text { Number of employees } \\
\text { through the measure/ } \\
\text { planned volume of } \\
\text { employment }\end{array}$ & 20,13 & 29,67 & 95,67 \\
\hline
\end{tabular}

Source: The Employment Office, internal data

Target group of unemployed persons

Number of employees through the measure/ planned volume of employment

Number of employees through the measure/number of requests received

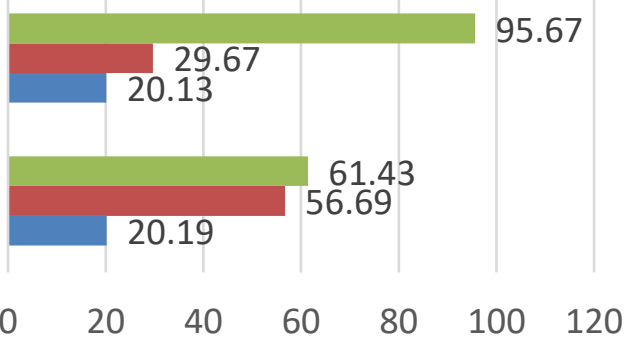

MEASURE Project for trainees: "With Knowledge to the job"

- MEASURE Project: "Together to the job"

MEASURE Social Welfare and Employment Networks Support Project

Figure 1. Planned and realized employment in \%

Source: The Employment Office, internal data 


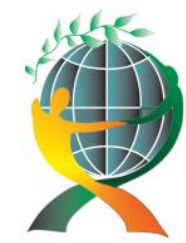

\author{
(online) = ISSN $2285-3642$ \\ ISSN-L = $2285-3642$ \\ Journal of Economic Development, Environment and People \\ Volume 10, Issue 3, 2021 \\ URL: http://jedep.spiruharet.ro \\ e-mail: office jedep@spiruharet.ro
}

\title{
Conclusions
}

ALMPs in the Republic of Srpska were not continuously conducted, but intermittently due to lack of funds, but also due to inadequate feedback on their performance. Namely, there is no systematic evaluation of the effectiveness of the implemented ALMP measures, which makes it difficult to assess which measures have achieved the goal, which should be adjusted, and which should be discarded as a means for the unemployed to get a job.

In the Republic of Srpska, there is a problem in assessing the effectiveness of certain measures, and that is inadequate IT support. The unemployed persons are not monitored according to all the characteristics that play a significant role in determining the target groups for individual measures. The measures are primarily intended for young people and categories that are in some connection with the last war conflicts in the former Yugoslavia: war invalids, children of killed soldiers and similar. When choosing the measures to be implemented, each governing structure prefers to opt for those that give results in the short term, and less often for measures whose effect would be felt only after a certain period of time, i.e. upon expiry of the term of the elected authority. It is also significant that these programs, at least to some extent, alleviate the problem of unemployment and, consequently, social exclusion.

The impact of ALMPs is difficult to measure, but the effectiveness of measures can be affected by targeting each active policy measure to the right target group of the unemployed, at the right time. The main conclusion is that these measures have the least impact on increasing the number of available jobs, but primarily on the re-allocation of employment opportunities, which means that the main goal of active labor market policies is to improve the position of hard-to-employ unemployed, not to create new jobs.

The international experience confirms that measures need to focus on small groups of the unemployed who need support at most, and that a combination of different measures has the best effect. The conducted evaluation of the effectiveness of individual ALMP measures speaks in favor of the above, because the example of war invalids confirmed the fact that the process of training and employment is the best form of their protection. For young people, it has been confirmed that through training, additional training, work practice, etc. it can affect employment, and strategies for young people should be developed in that direction.

In the Republic of Srpska, inadequate IT support is a major problem in assessing the effectiveness of certain measures. Unemployed persons are not monitored according to all characteristics, which play a significant role in determining the target groups for individual measures. The measures are primarily intended for young people and categories that are in some connection with the last war conflicts in the former Yugoslavia. The number of received requests is much higher than the realized employment. Although the largest number of participants was in the A1 project, according to the criterion of the planned/achieved employment, the most successful employment measure is intended for young people A3.

Evaluation of the individual measures effectiveness confirmed that these measures do not have a great impact on raising general employment. If the costs that accompany them are taken into account, the effect is further weakened. The answer to the question of solving the problem of unemployment lies in general economic growth. Healthy economic growth will lead to the creation of new jobs and to the suppression of the problem of unemployment.

The analysis of open issues of social exclusion in developed countries clearly shows that the fight against unemployment through ALMPs is recognized as a way to improve the position of socially isolated unemployed categories of the population. This struggle has been going on in the developed countries for 


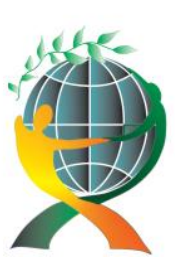

\author{
(online) = ISSN $2285-3642$ \\ ISSN-L = $2285-3642$ \\ Journal of Economic Development, Environment and People \\ Volume 10, Issue 3, 2021 \\ URL: http://jedep.spiruharet.ro \\ e-mail: office jedep@spiruharet.ro
}

more than thirty years, so it is not even possible to talk about the final effect of the measures implemented so far in the Republic of Srpska.

\title{
References
}

[1] Babic, Z. 2003. The role of active policy in the labor market in Croatia, Financial theory and practice 27 (4) 547566, Zagreb.

[2] Calmfors L. 1994. Active Labour Market Policy and Unemployment: A Framework for the Analysis of Crucial Design Features, OECD Economic Studies No. 22, Spring 1994.

[3] Card, D., Weber, A. \& Kluve, J. 2010. Active labor market policy evaluations: A meta-analysis, Working Paper 16173.

[4] Dar, A. \& Tzannatos, Z. 1999. Active Labor Market Programs: A Review of the Evidence from Evaluations, Social Protection Department, Human Development Network, World Bank.

[5] De Koning, J. \& Peers, Y. 2007. Evaluating ALMP evaluations, SEOR Working Paper No. 2007/2, Roterdam.

[6] Eichhorst, Werner \& Konle-Seidl, R. 2016. Evaluating Labour Market Policy Discussion Paper No. 9966 IZA, Bonn Germany.

[7] Fay, R. G. 1996. Enhancing the Effectiveness of Active Labour Market Policies: Evidence from Programme Evaluations in OECD Countries, OECD Labour Market and Social Policy Occasional Papers, No. 18, OECD Publishing.

[8] Harrell, A., Burt, M., Hatry, H. Rossman, S., Roth, J., Sabol, W. 1996. Evaluation Strategies for Human Services Programs, A Guide for Policymakers and Providers the Urban Institute Washington D.C.

[9] G Hujer R., Blienn, U., Caliendo, M., Zeiss, C. 2002. Macroeconometric Evaluation of Active Labour Market Policies in Germany - A Dynamic Panel Approach Using Regional Data, ERSA conference papers ersa02p225, European Regional Science Association.

[10] Lehmann, H., Kluve, J. 2010. Assessing Active Labour Market Policies in Transitional Economies, The Labour Market Impact of the EU Enlargement, Caroleo, F.E., Pastore, F. (ur.), Springer-Verlag Berlin Heidelberg: 275-307.

[11] Pierre, G. 1999. A framework for active labour market policy evaluation, Employment and Training Papers 49, International Labour Office, Geneva.

[12] Employment Office of the Republic of Srpska (2018), Activity report of the Public Institution of the Employment Office of the Republic of Srpska for 2018, available at http://www.zzzrs.net/dokumenti/izvjestaj 2018.pdf (accessed 10.09.2020)

[13] http://ec.europa.eu/eurostat/documents/3859598/5935673/KS-GQ-13-002-EN.PDF/bc4d9da7-b375-4eb3-97c7766ebf7b4aa0? version=1.0 (accessed 10.09.2020) 